\title{
The Effectiveness of Work Safety Training Among Workers with Low Educational Level towards the Attitudes of Work Safety Priority in Small, Medium and Large-Scale Industries
}

\author{
Djoko Kustono \\ Mechanical Engineering Department \\ Universitas Negeri Malang \\ Malang, Indonesia \\ kustono_djoko@yahoo.com
}

\begin{abstract}
The high rate of work accidents in East Java is mainly due to human factor, in this case, related to the low level of workers' attitudes towards the priority of work safety (MKK/Memprioritaskan Keselamatan Kerja). Theoretically, work safety training (PKK / Pelatihan Keselamatan Kerja) is able to improve the workers' attitude. This research intends to seek whether work safety training can equally influence the small, medium and large scale industries. The workers in industries in East Java are mostly the population with low level of education. In turn, the research found the significant effect of PKK on the improvement of the workers attitude but only at large scale industries. Whereas, this effect was not significant on the small and medium scale industries. Though the workers in small and medium scale industries have obtained the safety knowledge from work safety training, their attitude on safety did not increase as they have found a threat to apply their knowledge in their industries such as management system, facilities, working environment, and norms. Hence, based upon this finding, we suggest to the Manpower Ministry and other institution organizing the work safety training to pay more attention to small and medium scale industries. Also, the work safety training in small and middle scale industries should be followed with an additional supervision such as managerial system, safety environment, and safety norms.
\end{abstract}

Keywords - effectiveness, safety training, industrial scale

\section{INTRODUCTION}

East Java Province, located in Java Island, covers an area of $47.995 \mathrm{~km}^{2}$ with the population density of 804 persons in each $1 \mathrm{~km}$ square. The industry in East Java grows rapidly but this also triggers the high rate work accidents.

Accident refers to an unpredictable and unexpected incident. It is unpredictable as it does not have any intentional factor and it is unexpected as this incident is followed by the loss in materials and major or minor suffer. Data revealed by International Labour Organization (ILO) showed that around six thousand accidents claiming the fatal victims occurred every day in the world. In Indonesia, of 100 thousand workers, there are 20 cases of accident. "Data from Jamsostek (Labour and Social Assurance) showed that overall nine workers die in a day in which 3 people die in the workplace and six people die in the work relation [1]. A scientific oration of Open Session Senate in Universitas Negeri Malang revealed the data showing an increasing tendency from time to time started from 12.646 cases in 2000 up to 93.578 in 2013. There was a drastic increase of dead victim from 9.532 people in 2000 to 23.385 people in 2013. The real data, in fact, must be much higher as the data obtained from BPS ((Central Bureau of Statistics) commonly is based upon the official report of an institution; while the data that is not reported might not be recorded.

The age of the victims in work accident commonly becomes the core factor to analyze the seriousness of incident in work accident. The data about the work accident correlated with the age of the victims was then further presented showing that the workers with the productive age (16 to 50 years old) are at the top rank as the victims of work accident. In that interval, the young workers (16 to 25 years old) are those with the highest level as the victim of accident. Such condition is very apprehensive for all. In addition, the research showed that work accidents are mostly experienced by the workers with the low level of education (elementary school and lower secondary school).

Analysing the high rate of the work accident cases with the Domino Theory of Heinrich, then the human activities are becoming the major factor as the work accident has certain event sequence. The cause of the accident can be differentiated into two: mechanical hazard (uncontrolled energy source) and unsafe measure. Those two points occurred due to the human activities. Further, Heinrich in revealed that $88 \%$ of work accident is caused by the unsafe behaviour, while $12 \%$ is due to the other factors [2]. This statement is in line with what is mentioning that "unsafe behaviour is contributing cause of $85 \%$ of all accidents" [3].

From the fact shown above, the unsafe behaviour (of human) becomes the main factor of the work accident. Such behaviour is caused by the lack of awareness for the priority of the work safety. This is in line " human behaviour in relation to accident depends on attitudes of a person bring to each situations" [3].

The prevention program of work accident is commonly planned to develop the attitude of the priority of work safety 
(MKK) among employees. Attitude is defined as "the tendency to respond (positively or negatively) to certain object, person or situation". Such attitude development program is held by organizing the training and education for work safety as education is viewed as the best way to develop an attitude. Strasser argued that "education has been consistently Viewed as the method of safety promotion that will lead to the greatest degree of accident prevention" in addition, it also stated "safety education has responsibility of developing socially acceptable attitudes and modifying or changing unacceptable ones ".

In Indonesia, Work Safety Training (PKK) is officially organized by the Ministry of Labour in addition to certain companies holding this program individually. However, it raises two questions: (1) To what extent the effectiveness of education or training for the work safety can enhance an attitude to improve the priority of work safety (MKK) of the workers in industries in East Java in which most of the workers have the low level of education (Primary and Secondary School)? and are the effects of PKK different among the small, medium and large scale industries? Those two questions were revealed in this study. Work Safety Training refers to a series of activities that lead the participants (students) to have knowledge, understanding, skills, attitudes and values in work safety.

In general, the objectives of the PKK, include: 1) to develop awareness about the work safety; 2) to develop the prevention method of work safety; 3) to develop an attitude prioritizing the work safety (safe attitude), and 4) to integrate various definitions about the prevention of work accident into the structure of norms and philosophy of each member involved [3].

Attitude consists of the cognitive components (associated with thoughts and reasoning), affective component that is correlated with the emotion of an individual and the conation component as a tendency to behave.

Related to the research objective, then the object of the attitude meant is "prioritizing the work safety". The word "prioritizing" implies a meaning of selecting the work safety rather than other choices. Meanwhile, the term "work safety" is defined as the condition or state of being free from undergoing or causing hurt, injury or loss [4]. Work safety is the opposite of work accident. Accident is defined as an "unplanned event act or the resulting injury or death to persons or damage to property", and the emphasis in this formulation is the word of "unplanned" (unexpected) [3].

Based upon such definitions, the attitudes of MKK is interpreted as a tendency to prioritize all activities (whether affective, cognitive or connation) to reach the safe work conditions (free from any accident or damage causes). Any changes in attitude may occur with an intervention of stimuli to one or more components of attitude. If one or more components of attitude change, then there will be an interaction between components of attitude so as to form a new attitude balance.

According to trans-theoretical model intervention of attitude change should be started from the cognitive and affective side and then is continued in the conative side [5]. Thus, the initial stimuli are the cognitive and affective while the end is conative.Thus, this attitude, in fact, can be learned, formed and developed. The research by Strader M.K. reported in the Journal of Social Psychology in the edition of
April 1990 entitled Effect of persuasive communications on belief, attitudes and career choice towards 90 treatment groups and 90 control groups proved that the group given a persuasive treatment had a better attitude compared to the control group [6]. Similarly, the research of Da Silva entitled "Study of knowledge, attitude and practice of malaria patients in the use of drugs and the prevention of malaria in Matahoi Village, Vatalori District, Viqueque Regency, in East Timor Province towards 159 respondents indicated that the provision of information could constantly improve the knowledge, attitudes and actions of the respondents [7].

The process of attitude and values internalization as argued follows the hierarchy of (1) acceptance (receiving and attending), 2) the response (responding), 3) appraisal or reassurance (valuing), 4) organizing or conceptualization (organizing) and 5) characterization. The ultimate objective of attitude formation is the consistent daily behaviours [8]

The process of this attitude internalization can be formed such as through education. Research by Young DR as reported in American Journal of epidemiology edition of August 1996 entitled "Effect of community health education on physical activity, knowledge, attitude and behaviour: the Stanford five city project" towards 1056 male respondents and 1,183 female respondents revealed a positive effect of education on knowledge, attitude and physical activity of respondents [9].

In addition to the PKK, the change of the attitudes of MKK is also determined by work experience [10]. However, in this study the variable was used as the co-variance and statistically removed as the purpose of this research is to observe the real effect of PKK on small, medium and large scale industries on the attitude of MKK.

\section{METHOD}

The method used was ex post facto. The development of research methods is shown in the following stages: (1) conducting a qualitative research was the first stage aimed to obtain various verbal statements in some instruments that can be understood and interpreted uniformly by the respondents. (2) The second stage was by conducting the multi-level try out) aimed to obtain a method to measure the most suitable attitudes for use by the respondents in expressing their attitudes; (3) the third stage phase was related to the test of validity and reliability of instrument elements aimed to obtain the valid and reliable research instruments, and (4) the fourth stage was about data retrieval using the questionnaire and direct observation.

Direct observation aimed to discover the truth of the answers from the respondents. The observation was made by researcher through interviews with the direct supervisor of respondents. This method aimed to triangulate the respondents' answers.

The variable set as the dependent variable is the attitude of MKK. There are two independent variables set, namely (1) work safety training with stages with and without work safety training, (2) an industrial scale with stages (a) large scale industries, (b ) and medium scale industries (c) small scale industries.

The criteria of industrial scale used was the restriction from Susenas 1988 (National Economic Survey, 1988), stating that a small-scale industry is when the maximum 
number of employees is 25 people, medium-scale industry is between 26 and 100 employees, while large-scale industry is over 100 people. The limitation of industry according to this criterion refers to:

"Industry is a unit (unity) of production located in a specific place with an activity to change any less valuable goods to be the ones that have an added value with an aim to make the products closer to the ultimate consumer)"

In addition to the dependent variables of the attitude to prioritizing the work safety and the independent variable of work safety training as well as the scale of industry, this research also included the concomitant variable, namely work experience purposely to influence the final conclusion of the research. The existence of the concomitant variable could not be controlled physically; therefore, it is necessary to remove its influence so as not to affect the final conclusion.

Data analysis was carried out through the following stages: (1) to obtain the overall description about the research data conducted by presenting the mean scores and standard deviation for the group individually or in group. (2) The covariant variable was simplified using the correlation analysis of product moment and the factor analysis using the method of exploratory model analysis method; (3) the significance of the effectiveness of work safety training was observed by differentiating the workers in this case between those having the work safety training and those having no training among small, medium and large industries. Hence, the analysis used is the analysis of variance or ANOVA However, considering the existence of covariant variables, Anacova was applied then.

Based on these criteria, there have been six groups or cells manifested from two categories of work safety training and three categories of industry. In fact, the researcher found it difficult for the access to do interview in the industrial sites when doing triangulation. It then caused the number of respondents in each cell unequal. For this reasons, the analysis was performed using the "unequal N's" that is by firstly performing the categorical coding prior to the data processing. Categorical coding was performed for six cells: (1) a small-scale industry without training, (2) small-scale industry with training, (3) medium scale industry without training, (4) medium scale industry with training, (5) large scale industry without training and (6) large scale industry with training.

The requirements of analysis of covariance (Anacova) include: (1) normal distribution, (2) homogeny and (3) a regression form between the dependent variable and covariant variable linear [11-13]. Test on normality used Kolmogorov-Smirnov test with one sample, the homogeneity test used the statistics of Levene and linearity test used the regression analysis.

The mechanical workers working in industries in East Java became the population in this study. They have the educational level of Primary School and Secondary School. The sampling technique used was the stratified random sample. The number of sample was calculated in accordance with the formula Jacob Cohen and there were 100 subjects found then [14]. The distribution of respondents were 76 workers from 5 large scale industries, 20 workers from two medium scale industries and 15 workers from two small scale industries.

\section{RESULT AND DISCUSSION}

The descriptive statistics of Attitude to PKK is presented in Table 1. It was found out that PKK had an influence to improve the attitude of MKK only on the workers at the medium-scale and large scale industries. The quite significant improvement was found especially at the largescale industries.

TABLE I. Descriptive Statistics of Attitude to MKK

\begin{tabular}{|l|l|l|c|c|}
\hline No & $\begin{array}{c}\text { Scale of } \\
\text { Industry }\end{array}$ & PKK Group & $\begin{array}{c}\text { Average of } \\
\text { Attitude } \\
\text { Score }\end{array}$ & Deviation \\
\hline 1 & Small & Without PKK & 509,60 & 35,92 \\
& & With PKK & 505,33 & 16,04 \\
2 & \multirow{2}{*}{ Medium } & Total & 508,00 & 28,56 \\
& & Without PKK & 512,71 & 37,51 \\
& Large & With PKK & 524,40 & 19,83 \\
3 & & Total & 517,58 & 30,77 \\
& & Without PKK & 518,03 & 42,91 \\
4 & \multirow{2}{*}{ Total } & With PKK & 577,34 & 61,88 \\
& & Total & 556,65 & 62,56 \\
& & Without PKK & 516,14 & 40,54 \\
& & With PKK & 569,83 & 61,55 \\
\hline
\end{tabular}

The test on the analysis requirement referred to the test on normality and homogeneity, the result of the tests shown normal and homogeneous.

The results of the calculation of the analysis showed that at least one of the industrial scale (KOD) has shown a significant difference $(p<0,05)$ towards the change of the attitude of MKK. This difference was the effect of pure industrial scale after the covariant variables (disturber) of work experience has been removed. However, this test needed to be continued with the post hoc test to observe the ssignificance of the difference among the industrial scales. The results of the post hoc test are presented in Table 2 .

TABLE II. POST HOC TEST OF PKK

\begin{tabular}{|l|c|c|c|}
\hline & Small & Medium & Large \\
\hline Small & & $-9,58$ & $-48,65^{*}$ \\
\hline Medium & 9,58 & & $-39,07 *$ \\
\hline Large & $48,65 *$ & $39,07 *$ & \\
\hline
\end{tabular}

Table 2 shows a significant difference of attitude of MKK $(\mathrm{p}<0,05)$ between the large scale industries and the small -medium scale ones. The attitude of MKK among the workers in the large-scale industries was found higher compared to the attitude of MKK at small-medium scale industries. Whereas, the difference of attitude of MKK between medium scale industries and the small ones was insignificant.

To observe the effect of the work safety training in each industry, the ANOVA test was used. The results of the test are shown that (1) in large scale industry, the PKK has provided a significant effect $(p<0,05)$ on the attitude of MKK and this was proven with the significant difference of the attitude of MKK between the workers obtaining the PKK and those not obtaining such training; (2) in the medium scale industries, the PKK did not provide any significant effect $(p<0,05)$ on the attitude of MKK and this was proven with the absence of the significant difference of the attitude of MKK between the workers obtaining the PKK and those 
not obtaining such training and (3) in the small-scale industries, PKK did not give any significant effect $(\mathrm{p}<0,05)$ on the attitude of MKK and this can be proven with the absence of significant difference of the attitude of MKK between the workers obtaining the training of the work safety and those not obtaining such training.

The comparisons of the effect of PKK in building the attitude of MKK between the large-scale, medium scale and small scale industries were shown from statistical table informing that at the large scale industry the rate of the increase of the attitude of MKK caused by PKK was high. Meanwhile, at the medium scale industry the increase was insignificant. In contrast, there was not any effect of the PKK on the attitude of MKK at the small-scale industry.

Based on the results stated above, it was found that the PKK can significantly improve the attitude of MKK among the workers at the large scale industry. On the other hand, at the medium scale industry though it showed an increase, it was not significant and at the small scale industry, the Training of Work Safety did not have any effect on the attitude of MKK. This fact indicates that the infrastructure of industry also plays a role in increasing the attitude of MKK.

The examples of the internal drawback of the workers at the small scale industry in increasing the attitude of MKK could be explained as follows: (1) in training, the workers at the small-scale industries obtained the knowledge about the self-protection devices (APD) such as protector for ear, eyes, face and body and other. However, when they are in their industry, it was found that there was not any protection tool there or the tools were not sufficient. As a consequence, they work without any self-protection tools as they have done previously. (2) In the training, the workers at the small scale industry obtained the knowledge about the audit of work safety; in this case, about the procedure of auditing any procedures of work safety but when they go back to the industry, the management system in industry did not provide a sufficient access of audit of work safety. For this reason, the traditional method again has to be applied. (3) at the training, the workers at small-scale industry obtained the knowledge about hazard communication to provide any danger signals that might occur and decrease the work health but when they are in industry, it was found that the management system, work partners or existing tools did not or lack of support its implementation. As a consequence, the knowledge about hazard communication cannot be a change of the attitude of MKK. This fact is in line with the survey conducted by Kustono providing the following conclusion [10].

At small-scale industries in East Java, it is rare to be found any self-protection, engine protection or work safety tools, standard regulation of the production operation and the production sanitation. Such work condition has created an unsafe work; this, the risk for the work accident becomes high.

The examples above, however, did not occur in the large scale industries; even the workers in this industry have frequently known, experienced and applied some of the materials given in the work safety training. Hence, the work safety training is only as the reinforcement for some materials of lesson. In accordance with the Theory of Reason Action [10,15] any changes of the attitude have been influenced by (a) the confidence in the action to be done, (b) the output expected if doing the action and (c) evaluation on the result. It seems that in large scale industry those three points have obtained a support from the existing infrastructure and work atmosphere; while in small scale industry it did not take place making the change of attitude of MKK unable to be built.

If this fact is seen based upon the trans-theoretical model, then the workers with low level of education (primary school and lower secondary school) in the small scale industry seemed to be at the level of "pre-contemplative stage" [5]. In other words, they did not have any awareness of the risk from the unsafe behaviour yet; thus, the training of work safety was not sufficient to trigger the awareness for the attitude of prioritizing the work safety (MKK). To make such attitude built, it requires certain stimuli from the environmental and managerial norms. Therefore, training of work safety for the workers with low level of education at small scale industry must be supported with other efforts oriented to the creation of any environmental norms and managerial system supporting the creation of the attitude of MKK.

Based upon the explanation of the results and discussion above, it is suggested to the local government to concern more with Work Safety and Health (K3) among the workers with the low level of education in small scale industry. Recently, it is only concerned with the large scale industries to be familiar with $\mathrm{K} 3$.

The opportunity of the local autonomy should be applied to create any local regulation oriented to the $\mathrm{K} 3$ of the workers in small scale industries as if it is not implemented, these workers tend to always experience the health deterioration and work with high risk without any sufficient protection. Such condition certainly will weaken the competitiveness among the workers in small scale industry that later can trigger the social vulnerability as their business opportunity has been taken by foreign companies.

\section{CONCLUSION}

Work Safety Training (locally abbreviated as PKK) has a significant effect on improving the attitude to prioritize work safety (MKK) of workers in the large-scale industry. Meanwhile, in medium-scale industry, such improvement is insignificant and in small-scale industry, it showed no any effect on the attitude of MKK.

Any knowledge on the work safety obtained by the workers at small-scale industries failed to improve the attitude of MKK among the workers in view of the internal drawbacks such as in managerial system, existing facilities, health of work environment, or norms of safety.

The knowledge of work safety among the workers in the large scale industry obtained from the Training of Work Safety (PKK) do not only play a role to improve the attitude of MKK but also plays a role as a reinforcement of any work condition nearby. 


\section{REFERENCES}

[1] Daafi Armada, 2015. Norma K3 Dalam Konstruksi Bangunan. Disampaikan pada Diskusi publik yang diadakan di Lembaga Bantuan Hukum (LBH) Jakarta, Senin, 29 Juni 2015.

[2] Sugihardjo, Robert. 1999. Manajemen keselamatan kerja (safety management). Makalah seminar disajikan dalam Munas III Assosiasi Hiperkes dan Keselamatan Kerja Indonesia di Batu Malang dari tanggal 24 - 26 Februari 1999.

[3] Strasser, Marland., James, E. Aron and Ralph, C. Bacon. 1981. Fundamental of safety education. Third edition. New York: Macmillan Publishing Company, Inc.

[4] Roland, Harold, E dan Moriety, Brian. 1990. System safety and management. New York: John Willey \& son.

[5] Fishbein, Martin dan Guinan Mary. 1996. Behavioral sciences and public health: A necessary partnership for HIV prevention. Public health report. Supplement. vol 111. 1996. hal 5-10.

[6] Strader, M.K. and Katz, B.M. 1990. Effect of persuasive communication on beliefs, attitudes and career choice. Journal of social psychology. April, 1990. Hal $141-150$

[7] Da Silva, Valente. 1997. Studi pengetahuan, sikap dan tindakan penderita malaria dalam menggunakan obat dan pencegahan penderita malaria di desa Mantahoi, kecamatan Vatalori Kabupaten Viqueque, Timor Timur. Skripsi. Tidak dipublikasikan. Fakultas Kesehatan Masyarakat Universitas Airlangga.
[8] Bloom, Benjamin. S., J. Thomas, Hastings dan George, F. Mandaus. 1971. Handbook on formative and summative evaluation of student learning. New York: Mc Graw Hill.

[9] Young DR., Haskel Wl., Taylor CB dan Fortmann SP. 1996. Effect of community health education on physical activity knowledge, attitudes and behavior. Stanford Five-city project. American Journal of Epidemiology. Aug. 1. p 264-274

[10] Kustono, Djoko. 2000. Model interaksi antara pelatihan keselamatan kerja dengan pendidikan formal dalam membentuk sikap mengutamakan keselamatan kerja. Disertasi. Program Pascasarjana Universitas Airlangga.

[11] Sudjana. 1983. Teknik analisis regresi dan korelasi. Bandung: Penerbit Tarsito

[12] Steel, Robert G.D., James H. Torrie. 1991. Prinsip dan prosedure statistika. Terjemahan oleh: Bambang Sumantri. Jakarta: PT. Gramedia Pustaka Utama.

[13] Hadi, Sutrisno. 1986. Statistika Jilid 3 cetakan ke tiga. Yogyakarta: Yayasan Penerbit Fakultas Psikologi Universitas Gajahmada.

[14] Cohen, Jacob. 1977. Statistical power analysis for behavioral sciences. New York: Academic press.

[15] Smet, Bart. 1994. Psikologi kesehatan. Jakarta: PT. Gramedia Widiasarana Indonesia. 